\title{
Indirect Tax and Economic Growth in Nigeria: The Case of VAT
}

\author{
${ }^{1}$ OBAYORI, Joseph Bidemi, ${ }^{2}$ OMEKWE, Sunday Omiekuma Paul \\ ${ }^{I}$ Department of Economics, Faculty of Social Sciences, Nnamdi Azikiwe University, Awka, Nigeria. \\ ${ }^{2}$ Department of Economics, Faculty of Social Sciences, University of Port Harcourt, Nigeria
}

\begin{abstract}
This paper empirically investigated the impact of value added tax (VAT) on economic growth in Nigeria from 1994-2018. This was done against the background that VAT as an indirect tax was introduced by the Federal Government of Nigeria in 1993 to replace sales tax with the sole aim of increasing the revenue base of government and make funds available for developmental purposes. The aim of the study is to examine the effect of value added tax on economic growth in Nigeria and determine the impact of other tax revenues particularly, custom and excise duties on economic growth in Nigeria. Thus, secondary data on GDP, VAT revenues, custom and excise duties were sourced from CBN statistical bulletin. Also, ARDL technique was used to analyze data. The variables were subjected to ADF unit root test prior the ARDL and found to be stationary. The ARDL co-integration test showed that there is a long run association amongst the variables. The ARDL short run result showed that the value of VAT has a positive relationship with economic growth in Nigeria. Also, custom and excise duties revenue positively impacted on economic growth in Nigeria. Hence, it was concluded that Value Added Tax (VAT) as an indirect tax system in Nigeria has direct relationship with economic growth in Nigeria since its inception in 1994. It has contributed to the total revenue of the nation as a result of reduction in tax evasion. Based on the findings, the paper recommended that government should put in place adequate measure to ensure that revenue generated from VAT is effectively utilized to develop and grow the economy in order to better the lives of the citizenry.
\end{abstract}

KEY WORDS: $A D F, A R D L, V A T$, Growth, Indirect Tax.

\section{INTRODUCTION}

Tax is a critical tool of fiscal policy that helps in generating revenue to finance the activities of government and stimulate the growth and development of an economy. Tax could be categorized into direct or indirect. Example of direct tax which is enforced on individuals and factors of productions include; petroleum profit tax, personal income tax, capital gain tax while that of indirect which the consumers bear the final burden include; value added tax (VAT), custom and excise duties, import and export duties. Conversely, development indicators such as economic growth which measures the quantitative increase in the output of the economy is affected in the course of managing the economy (Akpakpan, 2000).

In Nigeria, the culture of insensitive to payment of tax nationwide has been the bane of successive government. In order to enlarge the tax net with slight ester strain and decrease tax avoidance so that greater portion of the collected revenue would get to the government of Nigeria was the introduction of value added tax (VAT) in 1993. Thus, value-added tax, also tagged as goods and services taxis a consumption tax placed on a product whenever value is added at each stage of the supply chain, from production to the point of sale. Similarly, it is a consumption tax imposed on the supply of goods and services which will be impossible to evade both by the rich and the poor, minor or major enterprises. Thus, it is an indirect tax system on the final consumer of goods.

In Nigeria, the value added tax was introduced in January 1994 to replace the sales tax which was narrow in scope in terms of tax revenue from goods and services. In other words, VAT is a wider tax system designed to increase revenue for government (Ofishe, 2015). This is because, Nigeria government observed that VAT has been a major contributor to total government revenues of many developing countries in Africa such as Benin Republic, Coted'ivore, Guinea, Kenya, Madagascar, Mauritius and Niger Republic who adopted the value added tax system 
(Ajakaiye, 2000). For instance, in earlier studies on VAT, Schaliziand Squire (1988) found out that VAT accounted for about 30\% of total revenue of Coted'ivore, Kenyaand Senegalin 1982. Similarly, Tait (1989) also observed that in Latin America, VAT accounts for $12.35 \%$ and $19.71 \%$ of total revenue in Ecuador and Mexico respectively a sat 1983. Thus, the remark able contribution of VAT to growth of the aforementioned nations and the target of the Nigerian government to raise her non-oil revenue base is the catalyst that speed up the institution of VAT.

More so, the dwindling in the international price of crude oil which is Nigeria's principal foreign exchange eamer as well as the increasing cost of running the government are some the many reasons that gave birth to VAT as effective tax system to gain more revenue (Afolayan\&Okoli, 2015).

Given the background above, the paper empirically examined the impact of VAT on economic growth in Nigeria by answering the following questions; what is the relationship between VAT and economic growth? How has others indirect tax system such as excise and custom duties contribute to economic growth in Nigeria? Thus, the objectives of the study were to; examine the relationship between value added tax and economic growth in Nigeria from 1994-2018 and determine the impact of custom and excise duties on Nigeria's economic growth.

\section{CONCEPTUAL FRAMEWORK}

Tax is the primary source of governmental revenue. It is an instrument for transferring resources from the private sector to the public sector in order to accomplish some of the nation's economic and social goals (Ekine, 2014). Taxes can be classified into two; namely, the direct and indirect taxes. The schematic view of the concept is presented in the figure below.

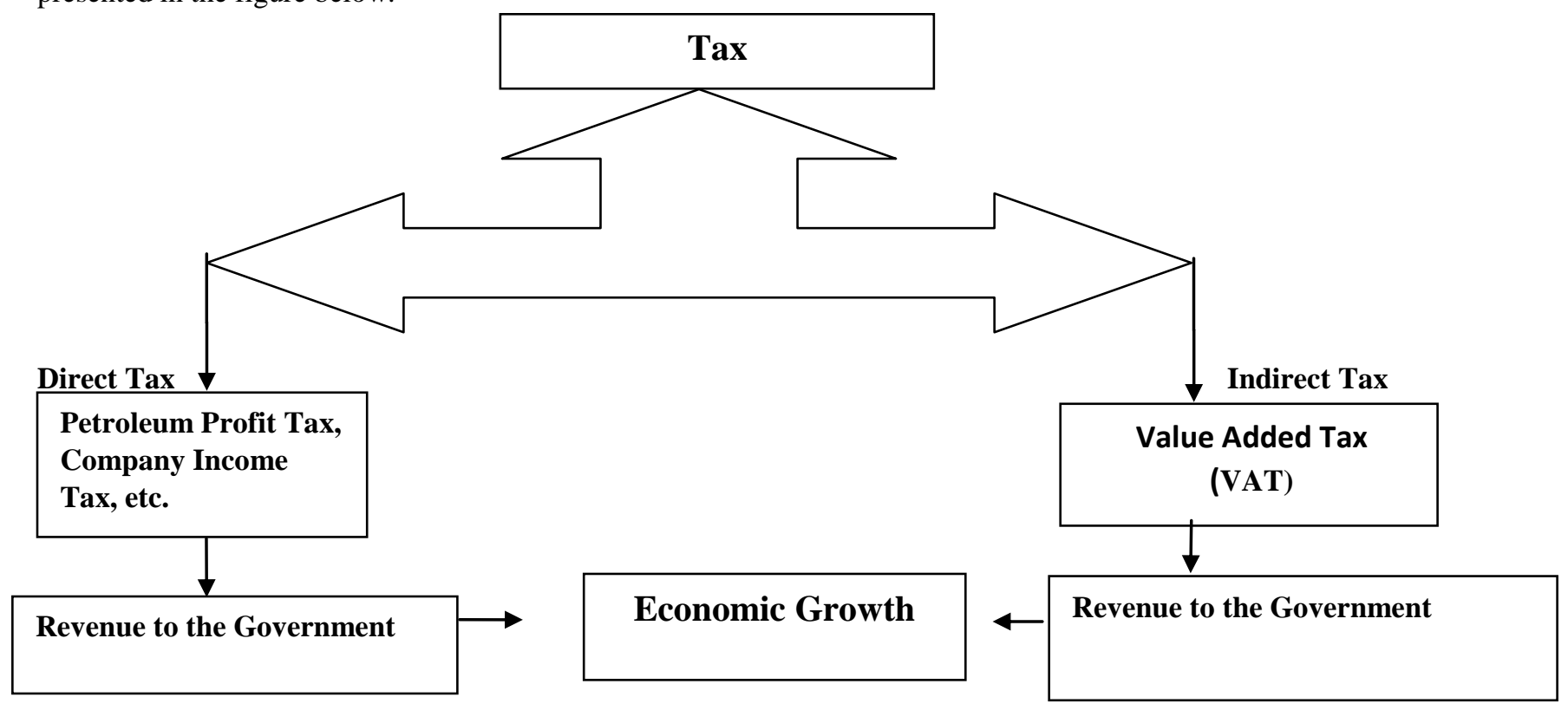

Figure 1:Schematic Presentation of the Concept of Tax

From the Figure 1 above, an increase in tax revenue, particularly value added tax (VAT) implies that more revenue is available for economic growth. Thus, it was assumed that the revenue generated from VAT will be expended on improving the socioeconomic well-being of the citizenry vis-à-vis improvement in education, housing, transportation, health, power, road construction, among other that will help the various sectors of the economy to function very well thereby enhancing the growth and development of the country.

\section{THEORETICAL AND EMPIRICAL REVIEW}

The theoretical foundation of the paper is the ability to pay theory of tax. This is because, it advocated that tax should be pay based on individual income. Here taxes are paid to the government base on the ability of the citizens. 
It is the most popular and mostly accepted principle of equitable tax. Thus, people that receives higher income are to pay higher taxes than those who receive lower income under this principle. That is collecting more from the rich to take care of the poor.

Similarly, different empirical works of scholars were reviewed. Inimino, Otubu and Akpan (2018) examined VAT and economic growth in Nigeria from 1994 to 2015 with the techniques of Co-integration and ECM and concluded that value added tax, exchange rate and interest rate all have significant relationship with economic growth in Nigeria during the period of study. While, private domestic investment has insignificant relationship with economic growth. Also, Gatawa, Aliero and Aishatu (2016) used co-integration and ECM techniques to examine the impact of VAT on economic growth in Nigeria. The result showed VAT positively impacted on GDP. Also, other source of revenue e.g oil receipt had appositive association with GDP. In 2014, Chigbu and Ali determines the nexuses between VAT and economic growth in Nigeria from 1994-2012 with the use of Engle-Granger co-integration technique on annual data covering 1994 to 2012. Their findings showed that VAT has positive effect on economic growth. OkuborandIzedonmi(2014) examined the contribution of VAT to the development of the Nigerian Economy. They employed time series data on the GDP, VAT revenue and total tax revenue from 1994 to 2010. They used both simple regression analysis. The result of their findings revealed that VAT revenue and total revenue account as much as 92\% significant variations in GDP in Nigeria. Also, Emmanuel (2013) used Simple Linear Regression method to investigate the effects of VAT on economic row hand total tax revenue in Nigeria from 1994 to 2010. The results showed that VAT significantly affect economic growth as well as aggregate revenue. In a similar vein, Gbegiand Okoye(2013) used Product Moment Correlation to examined VAT system. The findings revealed that revenue generated through VAT has a significant effect on total tax revenue in Nigeria.

Bakare(2013) investigated value added tax and output growth in Nigeria with the use of OLS. The study found positive and significant relationship exist between value added tax and output growth in Nigeria. An empirical findings of Basila (2010) while examining the connection between VAT and GDP with product moment correlation, showed that between 1994 and 2008, VAT has strong and positive relationship OF ABOUT 96\% strength with GDP.

\section{METHOOLOGY}

The data ranges from the period of 1994 to 2018. This data was mainly sourced from the publications of the Central Bank of Nigeria (CBN) statistical bulletin volume 29, 2018. This study adopted the descriptive statistics to test the reliability of data via mean, skewness and standard deviation. Also, the econometrics of method of ARDL model was used to explore the impact of the explanatory variables on the dependent variable. Meanwhile, preliminary test via descriptive statistics was carried out to ascertain the characteristic nature of the time series under consideration. Also, stationarity test via ADF unit root test was carried out to establish stability of the time series.

\section{Model Specification}

The ARDL co-integration long run model was formulated as follows:

$$
\begin{aligned}
\Delta \mathrm{GDP}=\beta 0+ & \beta 1 \mathrm{GDP}+\beta 2 \mathrm{VAT}+\beta 3 \mathrm{CED}+\sum_{i=1}^{n}+\Delta \beta 1 G D P-1+\sum_{i=1}^{n} \Delta \beta 2 \ln V A T-1+\sum_{i=1}^{n} \Delta \beta 3 \mathrm{CED} \\
-1+\mathrm{U} & \text { (1) }
\end{aligned}
$$

The short run estimate via the ECM was carried out in model 2 as stated below

$$
\begin{aligned}
\Delta \mathrm{GDP}= & \beta 0+ \\
& \beta 1 \mathrm{GDP}+\beta 2 \mathrm{VAT}+\beta 3 \mathrm{CED}+\sum_{i=1}^{n} \Delta \beta 1 G D P-1+\sum_{i=1}^{n} \Delta \beta 2 \mathrm{VAT}-1+\sum_{i=1}^{n} \Delta \beta 3 \mathrm{CED}-1 \\
& +\lambda E C M+\mathrm{U} \quad(2)
\end{aligned}
$$

Where; GDP is Gross Domestic Product, VAT is Value added tax, CED is Custom and excise duties, U is error term, $\beta_{0}, \beta_{1}-\beta_{3}$ are the estimate parameters, $U$ is the error term $\lambda$ is the coefficient of ECM.

\section{RESULTS AND DISCUSSION}


Table 1 Descriptive Statistics of the Variables

\begin{tabular}{|l|c|c|c|}
\hline \multicolumn{1}{|c|}{ VARIABLES } & GDP & VAT & CED \\
\hline Mean & 604289.9 & 305564.9 & 149180.8 \\
\hline Median & 578876.5 & 168800.0 & 60350.00 \\
\hline Maximum & 999068.2 & 710200.0 & 438300.0 \\
\hline Minimum & 275450.6 & 7261.000 & 1616.000 \\
\hline Std. Dev. & 268912.4 & 281763.8 & 162558.4 \\
\hline Skewness & 0.214970 & 0.385227 & 0.666226 \\
\hline Kurtosis & 1.553906 & 1.381752 & 1.906112 \\
\hline Jarque-Bera & 2.276037 & 3.212324 & 4.705695 \\
\hline Probability & 0.320453 & 0.200656 & 0.095098 \\
\hline
\end{tabular}

Source: Extracted from e-view 10

The descriptive statistics reported in Table 1 indicated that the approximate mean of real gross domestic product (GDP), value added tax (VAT) and custom and excise duties (CED) in million naira are 604289.9, 305564.9, and149180.8 respectively. In response, the standard deviation of real gross domestic product (GDP), value added tax (VAT), custom and excise duties (CED) in million nairaare;268912.4, 281763.8, and 162558.4 respectively. The skewness test which measures the slope of the variables showed positive values for all the variables. Thus, they were positively slope. The probability of Jarque-Bera statistics showed that the null hypothesis of the variables were accepted. Thus, the variables were not normally distributed. Thus, a stationarity was employed to stabiles the data before further econometric estimation.

Table 4.2: ADF Unit Root Test Results at Level and First Difference

\begin{tabular}{|l|l|l|l|l|l|l|}
\hline Variables & $\begin{array}{l}\text { ADF Test } \\
\text { @ Level }\end{array}$ & $\begin{array}{l}\text { Critical Value } \\
\text { @ 5\% (level) }\end{array}$ & $\begin{array}{l}\text { Order of } \\
\text { Integration }\end{array}$ & $\begin{array}{l}\text { ADF Test Statistic } \\
\text { @ } \mathbf{1}^{\text {st }} \mathbf{D i f f e r e n c e}\end{array}$ & $\begin{array}{l}\text { Critical Value } \\
@ \mathbf{5 \%}\left(\mathbf{1}^{\text {st }} \mathbf{D i f f} \text { ) }\right.\end{array}$ & $\begin{array}{l}\text { Order of } \\
\text { Integration }\end{array}$ \\
\hline GDP & -3.22782 & -3.02068 & Stationary & & -2.998064 & $\mathrm{I}(0)$ \\
\hline VAT & -0.160936 & -2.99187 & Not Stationary & -6.251498 & -2.9981064 & $\mathrm{I}(1)$ \\
\hline CED & -0.925199 & -2.99187 & Not Stationary & -6.648001 & \\
\hline
\end{tabular}

Source: Researcher's Computation from (E-view 9)

The order of each of the series as presented in Table 2 using the ADF tests showed that all the variables were not stationary at level. Thus, the variables were subjected to first difference and they became stationary at first difference. Since the all the variables were stationarity, the best regression results was obtained.

Table 3 ARDL Bounds Test Result for Co-integration Model

\begin{tabular}{|l|l|l|}
\hline \multicolumn{2}{|l|}{ Model } & F-Statistic $=5.00214$ \\
\hline (GDP,VAT, CED) & $\mathrm{K}=3$ \\
\hline Critical Values & Lower Bound & Upper Bound \\
\hline $10 \%$ & 3.17 & 4.14 \\
\hline $5 \%$ & 3.79 & 4.85 \\
\hline $1 \%$ & 5.15 & 6.36 \\
\hline
\end{tabular}

Source: An Extract from (E- view 9)

The ARDL bound test result presented in Table 3 showed clearly that there is a long run relationship amongst the variables (GDP, VAT and CED). This is because the computed F-statistic of about 5.00214 is higher than the upper critical bounds at $5 \%$ critical value. Therefore, the null hypothesis of no co-integration at $5 \%$ significance level for the model was rejected. Following the establishment of long-run co-integration relationship among the variables, the long-run and short-run dynamic parameters for the variables were obtained.

(C) 2019, IJSMS 
Table 4. ARDL Long Run Result for the Estimated Model

\begin{tabular}{|c|r|r|ll|}
\hline Regressors & Coefficient & t-Statistic & P-Value \\
\hline VAT & -0.018351 & -0.1782 & 0.8617 \\
\hline CED & 2.05573 & 9.17034 & 0.0000 \\
\hline C & 204389 & 11.6151 & 0.0000 \\
\hline
\end{tabular}

Source: An Extract from (E- view 9)

The estimated ARDL long run coefficient of value added tax (VAT) was negatively signed and insignificant with economic growth. Thus, there is an indirectrelationship between VAT and economic growth in Nigeria during the period under review. The long run result likewise revealed that custom and excise duties was positively signed and significant with economic growth. Meaning that there is a direct long run relationship between custom and excise duties and economic growth.

Table 4: ARDL Error Correction Model Result for the Estimated Model Dependent Variable: Gross Domestic Product

\begin{tabular}{|c|r|r|r|}
\hline Regressors & Coefficients & \multicolumn{1}{|c|}{ t-Statistic } & \multicolumn{1}{c|}{ P-Value } \\
\hline D(GDP(-1) & -2.73942 & -1.13588 & 0.2801 \\
\hline D(VAT) & 0.74886 & 1.64290 & 0.1287 \\
\hline D(CED) & 3.7530 & 2.2638 & 0.0448 \\
\hline ECT(-1) & -0.52107 & -2.65638 & 0.0143 \\
\hline $\mathrm{R}^{2}=0.76146$ & f-stat=3.51153 & Prob(f-stat) $=0.02534$ & DW Stat=1.8270 \\
\hline
\end{tabular}

Source: An Extract from (E- view 9)

Table 4 showed the result of the short-run dynamic result obtained from the ECM equation. The error correction term in the model has the right negative sign and statistically significant at 5\% level. This implies that deviations from the long-term economic growth adjust quickly to long run equilibrium at a speed of $52.1 \%$. The $\mathrm{R}^{2}$ value of $76 \%$, showed that the model is a good fit. The Durbin Watson (DW) value of 1.827 which is very close to $2.0 \mathrm{DW}$ bench mark, suggested that the model is free from serial autocorrelation problem.

Meanwhile, in the short run, the coefficient of lag value of GDP is negatively related with her current value but statistically not significant at 5\% level. Meaning the lag value of GDP reduces its current value by $273.9 \%$. On the other hand, the main independent variable (VAT) has a positive relationship with economic growth (GDP) but does not significantly impacted on economic growth during the period under review. What this implies is that the revenue generated from VAT has increase over time but the rate of increase has not be well utilize to impact on improving the welfare of the citizenry vis-à-vis good health care, education, employment amongst others. Meaning that the bulk of the revenue from VAT has been diversified to unprofitable venture by the government. Corruption in the system is another reason that could cause VAT not to impact meaningfully on the growth of the economy. This because, revenue generated for capital projects has overtime been embezzled by the people at the helm of affair at every level of government in Nigeria. No wonder Okowa (1997) averred that systemic corruption is a plague that bedevil the Nigerian economy. Price water house Coopers (PwC, 2016) also, opined that one of the channels through which corruption occurs is low governance effectiveness which will most certainly result in corruption. Little wonder Nigeria had a score of 28 on a scale of 100 in the 2016 list of most corrupt countries in the world according to Transparency International. Thus, corruption is associated with poor public finance management accrued from tax base.

Moreover, the short run analysis showed that the coefficient of custom and excise duties appeared with positive sign and statistically significant at 5\% level. Meaning that a unit increase in revenue from custom and excise duties will significantly impact on economic growth in Nigeria. 


\section{CONCLUSION}

This study used Auto Regressive Distribution Lagged (ARDL) model to investigate the impact of value added tax on economic growth from 1994-2018. This was done against the back ground that VAT was initiated with the aim of increasing the revenue base of government and make funds available for developmental purposes. Time series data on the GDP, VAT revenue, and custom and excise duties were sourced from CBN statistical bulletin. The variable were subjected to ADF unit root test prior the ARDL and found to be stationary. The ARDL cointegration test showed that there is a long run association amongst the variables. The ARDL short run result showed that the value of VAT has a positive relationship with economic growth (GDP) in Nigeria. Also, custom and excise duties revenue positively impacted on economic growth in Nigeria. Hence, it was concluded that VAT as an indirect tax system in Nigeria has direct relationship with economic growth in Nigeria since its inception in 1994. It has contributed to the total revenue of the nation by reducing tax evasion. Following the empirical findings of this study, the following recommendations a mongst others was made; Government should putin place adequate measure to ensure that revenue generated from VAT is effectively utilized to develop and grow the economy. Also, other sources of tax revenue such as custom and excise duties should be well managed in order to improve the lives of the citizenry.

\section{REFERENCES}

[1] Afolayan,S.M. \&Okoli, M.N. (2015). Theimpactof valueaddedtaxonNigerianeconomic growth:Aninvestigation. European Journal of Business and Management, 7(9), 226-236

[2] Ajakaiye, (2010).MacroeconomicEffectsofVATinNigeria:AComputableGeneralEquilibriumAnalysis. AfricanE c o n o m i c s ResearchConsortium (AERC), 92.

[3] Akpakpan, E.B. (2000). The Economy: Towards a new Type of Economics. Port Harcourt: Belpot Publishers.

[4] Bakare,A.S.(2013).ValueAddedTaxandOutput GrowthInNigeria. Proceedingsof8thAnnualLondonBusinessResearchConference ImperialCollege.London, UK,8-9July.

[5] Basila,D. (2010).InvestigatingtheRelationshipbetweenVATandGDP ofManagementCorporateGovernance,2(2), 65-72.

inNigerian Economy. Journal

[6] CBN (2018). Central Bank of Nigeria Statistical Bulletin, Volume 29, Abuja.

[7] Chigbu, E. E., \&Ali, P.T. (2014). An econometric analysis of the impact of VAT on economic growth in Nigeria, European Journal of Business Management, 6(18), 62-73

[8] Ekine, T, N. (2014). Macro-economic Dimensions of Competitive Indicator and Policy Performance. Port Harcourt: Dominus Publishers.

[9] Emmanuel,C.U.(2013).TheeffectofValueAddedTax(VAT)onthe EconomicGrowth inNigeriaJournal ofEconomic and Sustainable Development,4(6), 190-202.

[10] Gbegi, D.O. \&Okoye, E.J. (2013). EffectiveValueAdded Tax: Animperativeforwealth creation in Nigeria, Global Journals Inc. Vol. 13

[11] Gatawa, N.M.,Aliero, H.M. \&Aishatu, A.M. (2016). Evaluating the impactofvalue added tax on the economic growth of Nigeria. Journal of Accounting and Taxation, 8(6), 59-65

[12] Inimino, E.E., Otubu, O.P. \&Akpan, J.E. (2018). Value Added Tax and Economic Growth in Nigeria, International Journal of Research and Innovation in Social Science, 2(10), 211-219

[13] Ofishe,O.W. (2015).TheImpactofValueAddedTaxonEconomicGrowthinNigeria(1994-2012). Research Journal of Finance and Accounting, $6(23), 35-46$

[14] Okowa, W.J. (1997). Oil, Systemic Corruption, Abdullistic Capitalism and Nigerian Development Policy (A Political Economy). Port Harcourt: Jeson Services.

[15] PwC, (2016). Impact of Corruption on Nigeria's Economy. Retrieved on $12^{\text {th }}$ April, 2018 from www.pwc.com/ng

[16] Tait,A.(1989).VATRevenue,InflationandForeignTradeBalance.InGillis,M,Shoupo,C.SandSicat,G.P,ValueAddedTaxationinDevelopingCou ntries. Washington,D.C, World Bank.

(C) 2019, IJSMS

Page 66 